Published in final edited form as:

Biochem Biophys Res Commun. 2015 September 11; 465(1): 47-52. doi:10.1016/j.bbrc.2015.07.123.

\title{
ADCY7 supports development of acute myeloid leukemia
}

\author{
Chunling Li ${ }^{1,3}$, Jingjing Xie ${ }^{1,2,3}$, Zhigang Lu², Chen Chen ${ }^{1}$, Yancun Li ${ }^{1}$, Renhui Zhan ${ }^{1}, Y_{i}$ \\ Fang $^{2}$, Xuemei $\mathrm{Hu}^{1}$, and Cheng Cheng Zhang ${ }^{2,4}$ \\ ${ }^{1}$ Taishan Scholar Immunology Program, Binzhou Medical University, Yantai, Shandong 264003, \\ China \\ 2Departments of Physiology and Developmental Biology, University of Texas Southwestern \\ Medical Center, Dallas, Texas 75390, USA
}

\section{Abstract}

Acute myeloid leukemia (AML) is the most common adult acute leukemia. Despite treatment, the majority of the AML patients relapse within 5 years. In silico analysis of several available databases of AML patients showed that the expression of adenylate cyclase 7 (ADCY7) significantly inversely correlates with the overall survival of AML patients. To determine whether ADCY7 supports AML development, we employed an shRNA-encoding lentivirus system to inhibit adcy7 expression in human AML cells including U937, MV4-11, and THP-1 cells. The ADCY7 deficiency resulted in decreased cell growth, elvated apoptosis, and lower c-Myc expression of these leukemia cells. This indicates that $\mathrm{G}$ protein-coupled receptor signaling contributes to AML pathogenesis. Our study suggests that inhibition of ADCY7 may be novel strategy for treating leukemia.

\section{Introduction}

Acute myeloid leukemia (AML) is the most common adult acute leukemia. Treatments for AML yield poor outcomes, especially for the elderly patients. Even with continuous treatment, most AML patients relapse within 5 years [1]. The medical need for new therapies for AML is underscored by the fact that no new therapies for AML have been approved in more than 30 years.

Specific surface receptors and coupled signaling molecules play key roles in interaction between extrinsic environment and leukemia cells. It is known that signaling mediated by

\footnotetext{
${ }_{3}^{4}$ Corresponding Author: Cheng Cheng Zhang, Telephone (214) 645-6320, Fax (214) 648-1960, Alec.Zhang@ UTSouthwestern.edu. 3 These authors contributed equally

Competing interest disclosure

The authors declare no competing financial interests.

Author contributions

C.L., J.X., and C.C.Z. contributed to experimental design, performed experiments, interpreted data, and contributed to writing of the manuscript. Z.L., C.C., R.Z., Y. F., and X.H. performed experiments and interpreted data.

Publisher's Disclaimer: This is a PDF file of an unedited manuscript that has been accepted for publication. As a service to our customers we are providing this early version of the manuscript. The manuscript will undergo copyediting, typesetting, and review of the resulting proof before it is published in its final form. Please note that during the production process errors may be discovered which could affect the content, and all legal disclaimers that apply to the journal pertain.
} 
tyrosine kinase receptors [2], cytokine receptors [3], chemokine receptors [4], Notch [5], Wnt receptors [6,7], Smoothened [8], member of the TGF- $\beta$ receptor family [9], G proteincoupled receptors (GPCRs) [10], adhesion molecules, integrins [11,12,13,14,15,16], and other molecules regulate leukemia development. Some of these receptors mediate signaling that differs in leukemia cells from that in normal hematopoietic cells, which should enable the development of anti-leukemia-specific strategies $[16,17,18,19,20]$.

We have developed a systematic strategy to identify factors important for leukemia development [21]. We first use clinical databases to identify plasma membrane proteins that have correlations with the clinical outcomes of AML patients. We then validate the functions of candidate proteins in leukemia models and compare these functions to those in normal cells. The signaling pathways identified provide candidate targets for development of therapeutic approaches. Using this approach, we previously identified several ITIMcontaining receptors that support AML development [21,22].

Here we describe our finding that the expression of membrane protein ADCY7 is correlated with negative clinical outcomes in leukemia patients. Using a loss-of-function approach, we discovered that ADCY7 supports the survival of human AML cells, and c-Myc expression is decreased upon ADCY7 knockdown. ADCY7 is an effector of $\mathrm{Ga}_{12}$ and $\mathrm{Ga}_{13}$ signaling transmitted from surface GPCRs [23]; therefore, our results show that G protein-coupled signaling resulting from the interaction between the microenvironment and leukemia cells plays a key role in leukemia pathogenesis. ADCY7 is a promising target for AML treatment.

\section{Materials and methods}

\section{Cell culture}

Human leukemia cell lines were grown in RPMI-1640 medium (Hyclone, South Logan, UT, USA) supplemented with 10\% FBS (Gibco, Gaithersburg, MD). HEK293T cells were cultured in high glucose Dulbecco's modified Eagle's medium (Hyclone) supplemented with $10 \%$ FBS. All cell lines were maintained at $37{ }^{\circ} \mathrm{C}$ in $5 \% \mathrm{CO}_{2}$.

\section{shRNAs and primers}

Three sets of shRNAs were used in our study. The first two sets of shRNAs were designed based on an online program (http://rnaidesigner.lifetechnologies.com/rnaiexpress/). The third shRNA sequence was validated in a previous study [24]. RT-PCR primers were designed online (http://www.idtdna.com/site). The oligonucleotide sequences of the shRNAs used are:

Scrambled shRNA: 5'-GATATGTGCGTACCTAGCAT-3'

ADCY7 shRNA1: 5'-GGAATGGAGTCTGTTTAGA-3'

ADCY7 shRNA2: 5'-CACTTTATCGGTGACAAGTTA-3'

ADCY7 shRNA3: 5'-GGCAGGCAACTTTAGCACA-3' 


\section{Lentiviral shRNA constructs, lentiviral production, and cell transduction}

Lentivirus infection was performed essentially as we described [[22,25]][22,26,27]. The lentiviral vector Pl13.7 was used to express shRNAs designed to target adcy7 mRNA. For the lentiviral supernatant production, HEK-293T cells maintained in DMEM supplemented with $10 \%$ FBS and antibiotics were grown on $10-\mathrm{cm}$ culture plates to $\sim 60 \%$ confluence. For transfection, Polyjet (SignaGen, Rockville, MD, USA) was used according to the manufacture's protocol. For adcy7 inhibition, $5.5 \mu \mathrm{g}$ of the envelop plasmid $p M D 2 G, 2 \mu \mathrm{g}$ of the packaging plasmid PsPAX2, 7.5 $\mu \mathrm{g}$ of the shRNA lentiviral construct were dissolved in $0.5 \mathrm{~mL}$ of DMEM medium (serum and antibiotic free), Polyjet was added, and the solution was incubated for 15 min before addition to HEK293T cells. After 5 hours, the supernatant was discarded and replaced with $10 \mathrm{~mL}$ of DMEM with $10 \%$ FBS without antibiotics. After 48 hours, the supernatant was collected into a $15-\mathrm{mL}$ tube, and $10 \mathrm{~mL}$ of medium were added to the plate. This was repeated 72 hours later. The lentivirus-containing supernatant was filtered through a $20-\mu \mathrm{M}$ pore filter, and quickly frozen in liquid nitrogen for storage at $-80^{\circ} \mathrm{C}$. U937, MV4-11, and THP-1 cells were cultured in 6-well plates $\left(5 \times 10^{5}\right.$ cells/well), and 16 hours later were transduced with virus by addition of $1 \mathrm{~mL}$ of lentiviral supernatant diluted in $1 \mathrm{~mL}$ of DMEM complete medium and $4 \mu \mathrm{L}$ of protein sulfate. Cells were centrifuged at 2,000 rpm (Heraeus Biofuge Stratos centrifuge, ThermoScientific, Waltham, MA, USA) for $120 \mathrm{~min}$ at $37^{\circ} \mathrm{C}$. Cells were then cultured at 37 ${ }^{\circ} \mathrm{C}$ in $5 \% \mathrm{CO}_{2}$ for 5 hours. Culture medium was discarded, and cells were cultured in complete 1640 medium with 10\% FBS and antibiotics for 19 hours. This procedure was repeated for a second infection.

\section{Cell growth assays}

$\mathrm{GFP}^{+}$shRNA-encoding lentivirus-infected cells were sorted by flow cytometry two days post-infection and 20,000 cells were plated in $1.55-\mathrm{cm}$ wells. Cell numbers were determined on days 2,4 , and 6 in triplicate wells. The experiment was repeated three times with similar results.

\section{Apoptosis assay}

The apoptosis assay was performed using the Annexin V-PE apoptosis detection kit (eBioscience, San Diego, CA, USA) as we described previously ${ }^{[10,12]}$. Fluorescence signals from at least 10,000 cells were collected by FACS (Beckman, CA, USA) to determine the percentage of apoptotic cells.

\section{Quantitative real-time RT-PCR}

TRIzol reagent (Invitrogen, Carlsbad, CA, USA) was applied to total RNA extracted from cells or patient samples. Reverse transcription was performed using M-MLV reverse transcriptase cDNA Synthesis Kit (Takara Bio, Otsu, Shiga, Japan). Real-time RT-PCR was carried out on ABI 7900HT Fast Real-Time PCR System (Foster City, CA, USA) with SYBR-Green PCR Master Mix (Toyobo, Kita-ku, Osaka, Japan). A comparative CT method $\left(2^{-\Delta \Delta C T}\right)$ was used to quantify gene expression. $\beta$-actin was used as the internal control for normalization. The primers for $\beta$-actin were as follows: $\beta$-actin-F 5'AACACCCCAGCCATGTACG-3'; $\beta$-actin -R 5'-ATGTCACGCACGATTTCCC-3'. 


\section{Gene expression and survival analysis}

We analyzed publicly available gene expression datasets from human AML studies as described [21]. Data were obtained from the TCGA AML database (https://tcgadata.nci.nih.gov/tcga/, $\mathrm{n}=187$ ), the GSE6891 database (http://www.ncbi.nlm.nih.gov/geo/ query/acc.cgi?acc=GSE6891, $n=520)$, and the GSE10358 database $(n=91)$. Expression was normalized to total mRNA. Patients were separated into two groups based on whether they had higher or lower than the average expression levels of the ADCY7 to perform Kaplan-Meier survival analysis (GraphPad Prism, version 5.0, GraphPad, San Diego, CA, USA).

\section{Statistical analyses}

Data are expressed as means \pm SEM. Data were analyzed by Student's $t$-test and were considered statistically significant if $p<0.05$. The survival rates of the two groups were analyzed using a log-rank test and were considered statistically significant if $p<0.05$. p values are represented as precise $\mathrm{p}$ values or generally as $* \mathrm{p}<0.05$.

\section{Results}

\section{High expression of ADCY7 correlates with poor survival of AML patients}

To identify genes encoding membrane protein genes that potentially support leukemia development, we performed an in silico analysis of the relationship between gene expression and the overall survival of AML patients using data from three independent databases: the TCGA AML database (https://tcga-data.nci.nih.gov/tcga/; $n=187$ ), the GSE6891 database $(\mathrm{n}=520)$, and the GSE10358 database $(\mathrm{n}=91)$. Expression of genes encoding several membrane proteins, including IL2RA, GPR56, and ACDY7, inversely correlated with the overall survival of AML patients. Of these, IL2RA and GPR56 are known to play key roles in supporting leukemia development $[10,28]$. These published studies validated the effectiveness of our approach and suggest that the correlational data are predictive of functional roles in leukemia promotion.

ADCY7 is an adenylate cyclase with 12 membrane-spanning domains that catalyzes the formation of cyclic AMP from ATP. The adcy7 gene, located at 16q12-16q13 of the human genome, was previously cloned from a erythroleukemia cell line [29]. Regulation of signaling through $\mathrm{Ga}_{12}$ and $\mathrm{Ga}_{13}$ pathways converges on ADCY7 [23].

We compared the overall survival of AML patients with low versus high CCDC6, and observed that, in each dataset, the expression of $a d c y 7$ inversely correlated with the overall survival of AML patients (Fig. 1A-C). adcy7 mRNA was detected in cells from all subclasses of AML (Fig. 1D) and in mouse granulocyte/monocyte progenitors (GMPs) upon MLL-AF9 transformation (Fig. 1E). Because MLL-AF9 transformed GMPs are enriched for AML stem cells [30], this result suggests that ADCY7 is highly expressed by leukemia stem cells.

Gene expression analysis indicated that $a d c y 7$ mRNA is highly expressed in human monocytic and monoblastic AML cell lines U937, MV4-11, and THP-1 and in B 
lymphoblastic leukemia (B-ALL) cell lines 697, KOPN-8, and RCH-ACV (Fig. 2). This high expression of adcy7 in monocytic and monoblastic AML cells is consistent with its elevated expression in MLL-rearranged leukemia cells (Fig. 1E).

\section{ADCY7 is essential for the growth of human acute leukemia cells}

To study the potential function of ADCY7 in human leukemia, we inhibited the expression of ADCY7 by introducing lentivirus-encoded shRNAs designed to inhibit expression from adcy7 into U937, MV4-11, and THP-1 cells. The three shRNAs tested all efficiently decreased expression of ADCY7. shRNA3 had the greatest efficiency and was used to silence $a d c y 7$ in a previous report [24]; treatment of cells with this shRNA reduced $a d c y 7$ mRNA to $45 \%$ of the endogenous level (Fig. 3A).

The ADCY7 deficiency resulted from shRNA 1-3 decreased the in vitro growth of U937 cells to $66 \%, 76 \%$, and $58 \%$ respectively of that of control cells treated with a scrambled shRNA at 6 days after lentivirus infection (Fig. 3B). To determine the underlying mechanism by which ADCY7 supports the growth of these leukemia cells, we compared the cell cycle status and apoptosis of U937 cells treated with these shRNAs or scrambled control shRNA. No significant difference was observed in cell cycle distribution in these two treatment conditions (data not shown). However, ADCY7-deficient cells infected with shRNA3 had significantly increased levels of early apoptosis compared to cells treated with the control shRNA (Fig. 3C-D; 15.1\% early apoptotic cells in scramble control-treated cells vs. $28.7 \%$ in ADCY7-deficient cells at day 3 of culture). shRNA 1 and 2 also had similar effects on apoptosis induction (data not shown). Moreover, similar effects of inhibition of adcy7 expression on apoptosis were observed in MV4-11 and THP-1 cells (Fig. 3E-F). These results indicate that ADCY7 supports leukemia cell growth by suppressing apoptosis.

The inhibition of adcy7 expression decreased $c-M y c$ mRNA expression in both U937 cells and MV4-11 cells $(0.76 \pm 0.10 \%$ and $0.65 \pm 0.15 \%$ of amounts in scrambled control-treated cells, respectively, Fig. 4). By contrast, the expression of $p 21, p 53$, and survivin was not significantly altered in cells deficient in ADCY7 compared to control cells (data not shown). Our results clearly indicate that ADCY7 is essential for survival of these human AML cell lines, and suggest that ADCY7 acts through a pathway involving c-Myc.

\section{Discussion}

In this study, we demonstrated that the expression of an adenylate cyclase ADCY7 negatively correlates with the overall survival of AML patients. The gene encoding ADCY7 was upregulated upon the transformation of cells with an MLL-fusion oncogene.

Importantly, using a loss-of-function approach, we showed that ADCY7 supports leukemia development by decreasing apoptosis of AML cells. This is the first demonstration of ADCY7 function in cancer development and in the hematopoietic system.

The gene encoding ADCY7 was cloned from a erythroleukemia cell line [29] and is one of the nine membrane-spanning mammalian adenylate cyclases that catalyze intracellular cAMP production. ADCY7 is reportedly a downstream effector of the $\mathrm{Ga}_{12} / \mathrm{Ga}_{13}$ pathways [23] and has been shown to modulate affective neural circuitry [31]. ADCY7 also has a sex- 
specific role in depression and alcohol dependence [32,33,34]. Only 6\% of adcy7-knockout mice live to adulthood [32], suggesting that ADCY7 is essential in embryonic development. The function of ADCY7 in most tissues in the body is unclear, however.

GPCR- and $\mathrm{Ga}_{12} / \mathrm{Ga}_{13}$-mediated signaling has been linked to AML development. GPR56, a GPCR that is coupled with $\mathrm{Ga}_{12} / \mathrm{Ga}_{13}$ signaling and regulates cell adhesion and migration, maintains hematopoietic stem cell (HSC) pools by coordinating interactions between HSCs and the bone marrow osteosteal niche. GPR56 also supports cell adhesion and survival of EVI1 ${ }^{\text {high }}$ AML cells through RhoA signaling [10]. Because ADCY7 is coupled with $\mathrm{Ga}_{12} / \mathrm{Ga}_{13}$, signaling that is downstream of GPR56, it is possible that ADCY7 plays a role similar to that of GPR56 in AML development. Our study supports this hypothesis. Because ADCY7 is expressed by all subclasses of AML cells evaluated, it has potential as a treatment target for various types of AML. Further investigations into the potential connection between ADCY7 and GPR56 and other GPCRs are warranted. If a definitive signaling flow between a particular group of GPCRs and ADCY7 is established, targeting the upstream GPCR may be an effective strategy for treating AML.

Adenylate cyclases catalyze cAMP production. cAMP stimulates growth of many cell types but inhibits growth of others. cAMP inhibits survival of certain lymphoma and chronic lymphocytic leukemia (CLL) cells [35]. By contrast, cAMP protects acute promyelocytic leukemia (APL) cells against anthracycline-induced apoptosis and thus promotes progression of this type of AML [36]. Here we showed that the deficiency of ADCY7 in AML cells decreased the expression of c-Myc. This is in line with the reported regulation of c-Myc expression by the cAMP cascade in thyrocytes [37]. Future work will be needed to determine whether cAMP is a key second messenger downstream of ADCY7. If this is the case, identification of the downstream effectors to which it transmits the signaling will help clarify the roles of cAMP in different subtypes of leukemia.

\section{Acknowledgments}

We would like to acknowledge the support of this project by NIH grant 1R01CA172268, Leukemia \& Lymphoma Society Awards LLS\#1024-14 and LLS\#6024-14-01, the CPRIT RP140402 award, and the Taishan Scholar Program.

\section{References}

1. Maynadie M, Girodon F, Manivet-Janoray I, Mounier M, Mugneret F, Bailly F, Favre B, Caillot D, Petrella T, Flesch M, Carli PM. Twenty-five years of epidemiological recording on myeloid malignancies: data from the specialized registry of hematologic malignancies of Cote d'Or (Burgundy, France). Haematologica. 2011; 96:55-61. [PubMed: 20971817]

2. Fathi A, Levis M. FLT3 inhibitors: a story of the old and the new. Curr Opin Hematol. 2011; 18:7176. [PubMed: 21245757]

3. Vainchenker W, Constantinescu SN. JAK/STAT signaling in hematological malignancies. Oncogene. 2013; 32:2601-2613. [PubMed: 22869151]

4. Broxmeyer HE. Chemokines in hematopoiesis. Curr Opin Hematol. 2008; 15:49-58. [PubMed: 18043246]

5. Weng AP, Ferrando AA, Lee W, Morris JPt, Silverman LB, Sanchez-Irizarry C, Blacklow SC, Look AT, Aster JC. Activating mutations of NOTCH1 in human T cell acute lymphoblastic leukemia. Science. 2004; 306:269-271. [PubMed: 15472075] 
6. Zhao C, Blum J, Chen A, Kwon HY, Jung SH, Cook JM, Lagoo A, Reya T. Loss of beta-Catenin Impairs the Renewal of Normal and CML Stem Cells In Vivo. Cancer Cell. 2007; 12:528-541. [PubMed: 18068630]

7. Wang Y, Krivtsov AV, Sinha AU, North TE, Goessling W, Feng Z, Zon LI, Armstrong SA. The Wnt/beta-catenin pathway is required for the development of leukemia stem cells in AML. Science. 2010; 327:1650-1653. [PubMed: 20339075]

8. Zhao C, Chen A, Jamieson CH, Fereshteh M, Abrahamsson A, Blum J, Kwon HY, Kim J, Chute JP, Rizzieri D, Munchhof M, VanArsdale T, Beachy PA, Reya T. Hedgehog signalling is essential for maintenance of cancer stem cells in myeloid leukaemia. Nature. 2009; 458:776-779. [PubMed: 19169242]

9. Krause DS, Fulzele K, Catic A, Sun CC, Dombkowski D, Hurley MP, Lezeau S, Attar E, Wu JY, Lin HY, Divieti-Pajevic P, Hasserjian RP, Schipani E, Van Etten RA, Scadden DT. Differential regulation of myeloid leukemias by the bone marrow microenvironment. Nat Med. 2013; 19:15131517. [PubMed: 24162813]

10. Saito Y, Kaneda K, Suekane A, Ichihara E, Nakahata S, Yamakawa N, Nagai K, Mizuno N, Kogawa K, Miura I, Itoh H, Morishita K. Maintenance of the hematopoietic stem cell pool in bone marrow niches by EVI1-regulated GPR56. Leukemia. 2013; 27:1637-1649. [PubMed: 23478665]

11. Jin L, Hope KJ, Zhai Q, Smadja-Joffe F, Dick JE. Targeting of CD44 eradicates human acute myeloid leukemic stem cells. Nat Med. 2006; 12:1167-1174. [PubMed: 16998484]

12. Krause DS, Lazarides K, von Andrian UH, Van Etten RA. Requirement for CD44 in homing and engraftment of BCR-ABL-expressing leukemic stem cells. Nat Med. 2006; 12:1175-1180. [PubMed: 16998483]

13. Miller PG, Al-Shahrour F, Hartwell KA, Chu LP, Jaras M, Puram RV, Puissant A, Callahan KP, Ashton J, McConkey ME, Poveromo LP, Cowley GS, Kharas MG, Labelle M, Shterental S, Fujisaki J, Silberstein L, Alexe G, Al-Hajj MA, Shelton CA, Armstrong SA, Root DE, Scadden DT, Hynes RO, Mukherjee S, Stegmaier K, Jordan CT, Ebert BL. In Vivo RNAi screening identifies a leukemia-specific dependence on integrin beta 3 signaling. Cancer Cell. 2013; 24:4558. [PubMed: 23770013]

14. Chao MP, Alizadeh AA, Tang C, Myklebust JH, Varghese B, Gill S, Jan M, Cha AC, Chan CK, Tan BT, Park CY, Zhao F, Kohrt HE, Malumbres R, Briones J, Gascoyne RD, Lossos IS, Levy R, Weissman IL, Majeti R. Anti-CD47 antibody synergizes with rituximab to promote phagocytosis and eradicate non-Hodgkin lymphoma. Cell. 2010; 142:699-713. [PubMed: 20813259]

15. Jan M, Chao MP, Cha AC, Alizadeh AA, Gentles AJ, Weissman IL, Majeti R. Prospective separation of normal and leukemic stem cells based on differential expression of TIM3, a human acute myeloid leukemia stem cell marker. Proc Natl Acad Sci U S A. 2011; 108:5009-5014. [PubMed: 21383193]

16. Horton SJ, Huntly BJ. Recent advances in acute myeloid leukemia stem cell biology. Haematologica. 2012; 97:966-974. [PubMed: 22511496]

17. Lane SW, Scadden DT, Gilliland DG. The leukemic stem cell niche: current concepts and therapeutic opportunities. Blood. 2009; 114:1150-1157. [PubMed: 19401558]

18. Heidel FH, Mar BG, Armstrong SA. Self-renewal related signaling in myeloid leukemia stem cells. Int J Hematol. 2011; 94:109-117. [PubMed: 21800073]

19. Konopleva MY, Jordan CT. Leukemia stem cells and microenvironment: biology and therapeutic targeting. J Clin Oncol. 2011; 29:591-599. [PubMed: 21220598]

20. Sands WA, Copland M, Wheadon H. Targeting self-renewal pathways in myeloid malignancies. Cell Commun Signal. 2013; 11:33. [PubMed: 23675967]

21. Kang X, Lu Z, Cui C, Deng M, Fan Y, Dong B, Han X, Xie F, Tyner JW, Coligan JE, Collins RH, Xiao X, You MJ, Zhang CC. The ITIM-containing receptor LAIR1 is essential for acute myeloid leukaemia development. Nat Cell Biol. 2015; 17:665-677. [PubMed: 25915125]

22. Zheng J, Umikawa M, Cui C, Li J, Chen X, Zhang C, Hyunh H, Kang X, Silvany R, Wan X, Ye J, Canto AP, Chen SH, Wang HY, Ward ES, Zhang CC. Inhibitory receptors bind ANGPTLs and support blood stem cells and leukaemia development. Nature. 2012; 485:656-660. [PubMed: 22660330] 
23. Jiang LI, Collins J, Davis R, Fraser ID, Sternweis PC. Regulation of cAMP responses by the G12/13 pathway converges on adenylyl cyclase VII. J Biol Chem. 2008; 283:23429-23439. [PubMed: 18541530]

24. Coyne CB, Bozym R, Morosky SA, Hanna SL, Mukherjee A, Tudor M, Kim KS, Cherry S. Comparative RNAi screening reveals host factors involved in enterovirus infection of polarized endothelial monolayers. Cell Host Microbe. 2011; 9:70-82. [PubMed: 21238948]

25. Deng M, Lu Z, Zheng J, Wan X, Chen X, Hirayasu K, Sun H, Lam Y, Chen L, Wang Q, Song C, Huang N, Gao GF, Jiang Y, Arase H, Zhang CC. A motif in LILRB2 critical for Angptl2 binding and activation. Blood. 2014; 124:924-935. [PubMed: 24899623]

26. Xie J, Chen X, Zheng J, Li C, Stacy S, Holzenberger M, Hu X, Zhang C. IGF-IR determines the fates of BCR/ABL leukemia. J Hematol Oncol. 2015; 8:3. [PubMed: 25648584]

27. Chen X, Zheng J, Zou Y, Song C, Hu X, Zhang CC. IGF binding protein 2 is a cell-autonomous factor supporting survival and migration of acute leukemia cells. J Hematol Oncol. 2013; 6:72. [PubMed: 24191913]

28. Kobayashi CI, Takubo K, Kobayashi H, Nakamura-Ishizu A, Honda H, Kataoka K, Kumano K, Akiyama H, Sudo T, Kurokawa M, Suda T. The IL-2/CD25 axis maintains distinct subsets of chronic myeloid leukemia-initiating cells. Blood. 2014; 123:2540-2549. [PubMed: 24574458]

29. Hellevuo K, Berry R, Sikela JM, Tabakoff B. Localization of the gene for a novel human adenylyl cyclase (ADCY7) to chromosome 16. Hum Genet. 1995; 95:197-200. [PubMed: 7860067]

30. Krivtsov AV, Twomey D, Feng Z, Stubbs MC, Wang Y, Faber J, Levine JE, Wang J, Hahn WC, Gilliland DG, Golub TR, Armstrong SA. Transformation from committed progenitor to leukaemia stem cell initiated by MLL-AF9. Nature. 2006; 442:818-822. [PubMed: 16862118]

31. Joeyen-Waldorf J, Nikolova YS, Edgar N, Walsh C, Kota R, Lewis DA, Ferrell R, Manuck SB, Hariri AR, Sibille E. Adenylate cyclase 7 is implicated in the biology of depression and modulation of affective neural circuitry. Biol Psychiatry. 2012; 71:627-632. [PubMed: 22264442]

32. Hines LM, Hoffman PL, Bhave S, Saba L, Kaiser A, Snell L, Goncharov I, LeGault L, Dongier M, Grant B, Pronko S, Martinez L, Yoshimura M, Tabakoff B. A sex-specific role of type VII adenylyl cyclase in depression. J Neurosci. 2006; 26:12609-12619. [PubMed: 17135423]

33. Desrivieres S, Pronko SP, Lourdusamy A, Ducci F, Hoffman PL, Wodarz N, Ridinger M, Rietschel M, Zelenika D, Lathrop M, Schumann G, Tabakoff B. Sex-specific role for adenylyl cyclase type 7 in alcohol dependence. Biol Psychiatry. 2011; 69:1100-1108. [PubMed: 21481845]

34. Nelson EJ, Hellevuo K, Yoshimura M, Tabakoff B. Ethanol-induced phosphorylation and potentiation of the activity of type 7 adenylyl cyclase. Involvement of protein kinase $\mathrm{C}$ delta. $\mathbf{J}$ Biol Chem. 2003; 278:4552-4560. [PubMed: 12454008]

35. Murray F, Insel PA. Targeting cAMP in chronic lymphocytic leukemia: a pathway-dependent approach for the treatment of leukemia and lymphoma. Expert Opin Ther Targets. 2013; 17:937949. [PubMed: 23647244]

36. Gausdal G, Wergeland A, Skavland J, Nguyen E, Pendino F, Rouhee N, McCormack E, Herfindal L, Kleppe R, Havemann U, Schwede F, Bruserud O, Gjertsen BT, Lanotte M, Segal-Bendirdjian E, Doskeland SO. Cyclic AMP can promote APL progression and protect myeloid leukemia cells against anthracycline-induced apoptosis. Cell Death Dis. 2013; 4:e516. [PubMed: 23449452]

37. Pirson I, Coulonval K, Lamy F, Dumont JE. c-Myc expression is controlled by the mitogenic cAMP-cascade in thyrocytes. J Cell Physiol. 1996; 168:59-70. [PubMed: 8647923] 


\section{Highlights}

1. The expression of ADCY7 negatively correlates with the overall survival of AML patients.

2. ADCY7 supports growth of human AML cells by inhibiting apoptosis.

3. Knockdown of ADCY7 decreases c-Myc expression in human AML cells. 


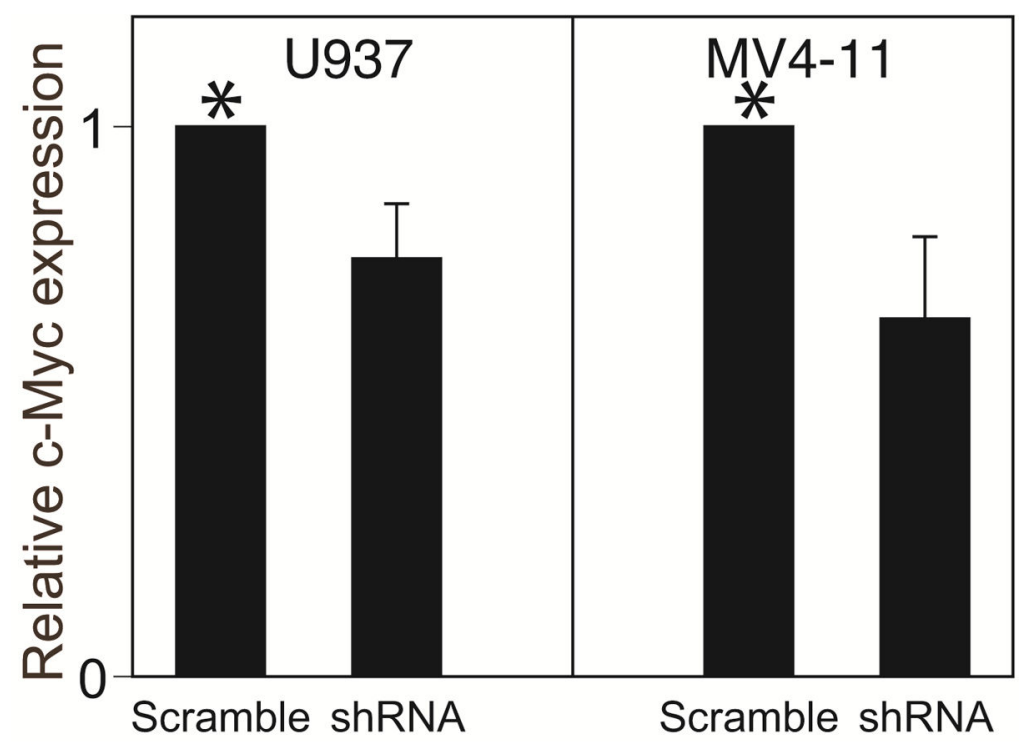

Figure 1. adcy7 mRNA expression negatively correlates with overall survival of AML patients (A-C) adcy7 mRNA expression data from (A) the TCGA AML database $(\mathrm{n}=187)$, (B) the GSE6891 database $(n=520)$, and $(C)$ the GSE10358 database $(n=91)$ were normalized to total mRNA expression. Patients were separated into two groups based on whether expression of adcy 7 was higher of lower than the average expression levels, and \% survival vs. time was plotted. (D) An in silico analysis of human adcy7 mRNA expression in human AML subclasses M1 through M7. Data were obtained from the TCGA AML database. (E) An in silico analysis of adcy7 mRNA expression in normal GMPs $\left(\mathrm{Lin}^{-} \mathrm{Kit}^{+} \mathrm{Sca}-1^{-} \mathrm{CD} 34^{+} \mathrm{CD} 16 / 32^{+}\right.$cells) and MLL-AF9-infected GMP cells. Data were obtained from GDS3839/1456307_s_at/Adcy7. 


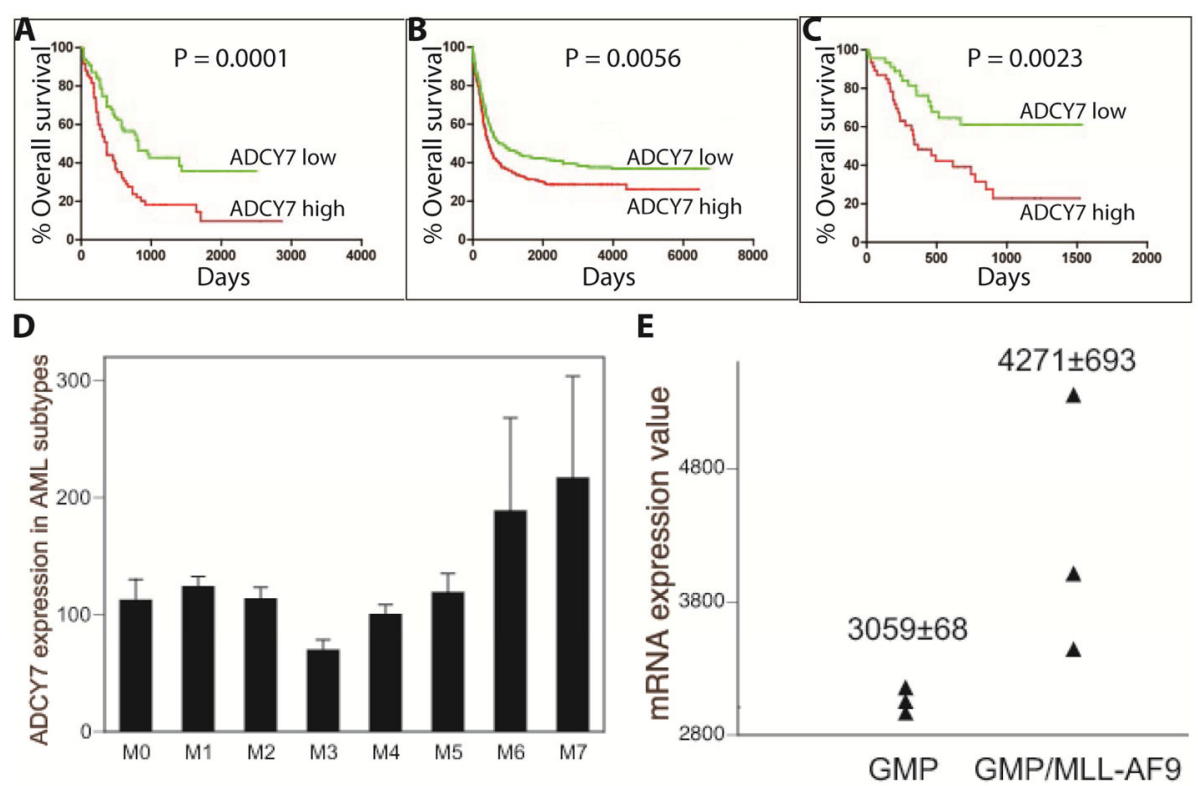

Figure 2. ADCY7 is highly expressed in human AML cell lines adcy7 mRNA expression (relative fold changes to that in NALM-6 cells) as determined by real-time RT-PCR plotted for human monocytic and monoblastic AML and B-ALL cell lines. Technical replicate $n=3$. 


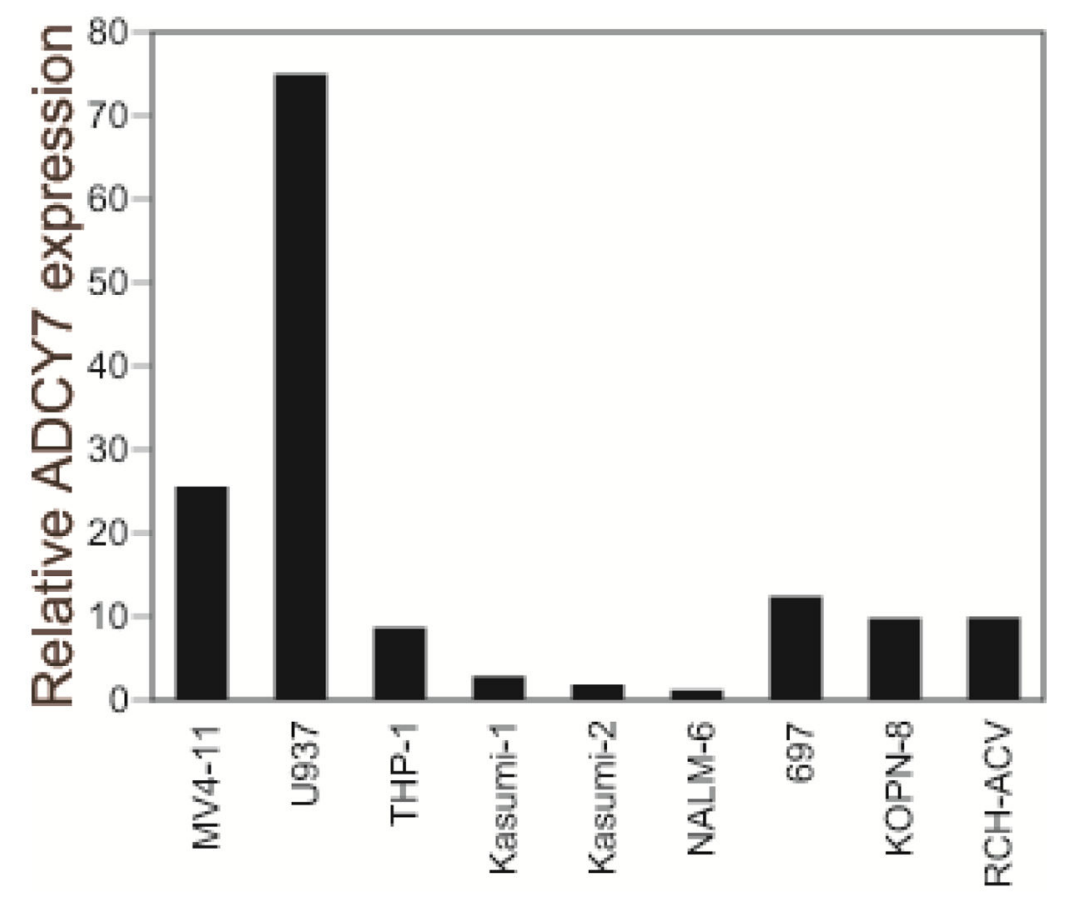

Figure 3. Inhibition of adcy7 expression significantly decreased cell growth and induced apoptosis of U937, MV4-11, and THP-1 AML cells

(A) Endogenous adcy7 expression was inhibited in 293T cells transfected with shRNAs targeting adcy 7 mRNA but not with a scrambled control shRNA as determined by real-time RT-PCR at 48 hours after lentiviral infection $(n=3)$. (B) Inhibition of adcy7 expression by three different shRNAs significantly decreased growth of U937 cells at 6 days post-infection when compared to growth of cells that express a scrambled control shRNA $(n=4)$. (C-D) ADCY7 deficiency induced apoptosis of U937 cells at $72 \mathrm{hr}$ post treatment with shRNA3 or a scrambled control shRNA. (C) Representative flow cytometry plots. (D) Plots of percent apoptotic cells ( $\mathrm{n}=3$, *, $\mathrm{p}<0.05$, Student's $t$-test). (E) MV4-11 and (F) THP-1 AML cells were treated with shRNA3 or a scrambled control shRNA. Percent of apoptotic cells were determined at $96 \mathrm{hr}(\mathrm{n}=3, *, \mathrm{p}<0.05$, Student's $t$-test $)$. 

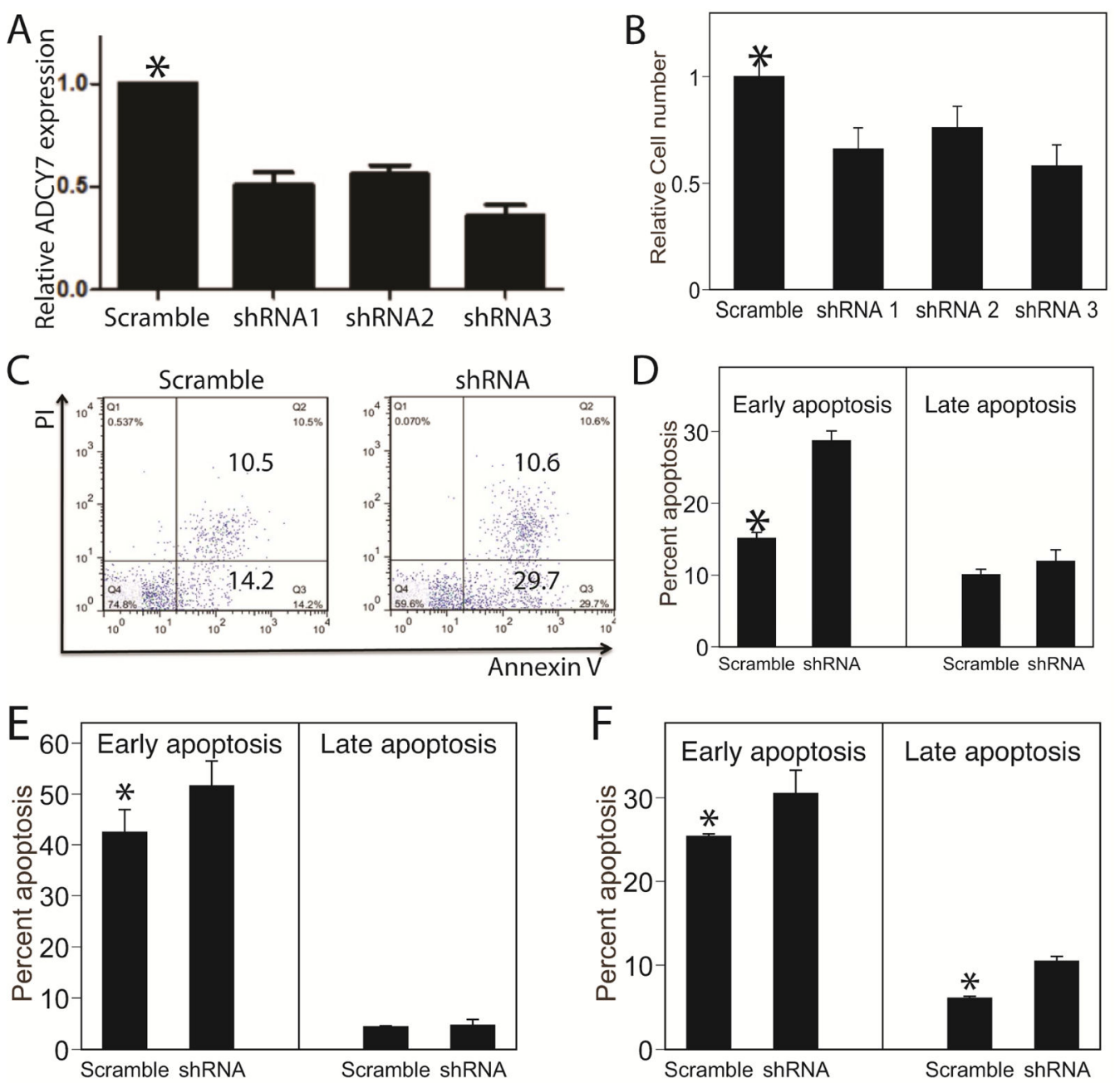

Figure 4. Lack of ADCY7 significantly decreased c-Myc mRNA expression in AML cells Expression of c-Myc was quantified in U937 cells and MV4-11 cells at $96 \mathrm{hr}$ post transfection with shRNA3 or a scrambled control shRNA by real-time RT-PCR $(\mathrm{n}=6, *, \mathrm{p}$ $<0.05$, Student's $t$-test). 